\title{
Equity Financing, Debt Financing, and Financial Performance in Islamic Banks
}

\author{
Heri Sudarsono $^{1 *}$, Jannahar Saddam Ash Shidiqie ${ }^{2}$ \\ ${ }^{1,2}$ Fakultas Bisnis dan Ekonomika, Universitas Islam Indonesia, Yogyakarta, Indonesia
}

Submitted: 3 July, 2021; Accepted: 30 December, 2021; Published: 8 January, 2022

\begin{abstract}
This research aims to determine the effect of bank size (SIZE), profitability (ROA), efficiency (EFF), non-performing finance (NPF), interest (INTR), and inflation (INFL) on profit and loss sharing (PLS) financing (equity financing), and sale-purchase (SP) financing (debt financing) Islamic banks in Indonesia. Furthermore, monthly Islamic bank data in June 2014 to July 2020 was used. The autoregressive distributed lag (ARDL) method was used to determine the short and long-term effects of the independent variables on the financing variable. The results showed that ROA and EFF have a positive effect on MRF but ROA and EFF have a negative effect on MDA and MSF. NPF has a positive effect on MDF, but has a negative effect on MRF. Meanwhile, SIZE has a negative effect on MDF, MDA, MRF, and MRA. The INTR has a negative effect on MDA, MRF, and MRA. The implication of this research is that financial performance has more influence on debt financing compared to equity financing of Islamic banks in Indonesia.
\end{abstract}

Keywords: Islamic bank, equity financing, debt financing, autoregressive distributed lag 


\section{INTRODUCTION}

Islamic banks mobilize funds through mudharaba products that use the profit and loss sharing (PLS) principle and wadiah products that use the deposit principle. It enables investment managers to utilize public funds for allocation to potential sources of income (Ariffin, Kassim, \& Razak, 2015). The income of Islamic banks comes from financing products that apply PLS principle, namely mudharabah and musharaka, including financing products that use the principle of sale and purchase (SP), such as murabaha, salam, and istishna, as well as ijarah products which involve leasing (Zulkhibri, 2018).

Several Islamic banks have a larger portion of financing based on the principle of SP compared to PLS and leasing (Abedifar, Molyneux, \& Tarazi, 2013; Miah \& Suzuki, 2020). Compared to musharaka and mudaraba, the large proportion of murabaha financing products is due to the principle of SP which provides more certainty of return and can minimize moral hazard (Aggarwal \& Yousef, 2000; Alam \& Parinduri, 2017). Furthermore, Islamic bank managers tend to select murabaha products because banks can predict long-term financing profits. The projection of future profits is required by the bank to determine policies for the optimal financing portion for each product.

From the report of the Financial Services Authority (OJK), during June 2014 to July 2020, it is observed that murabaha financing is higher than musharakha and mudharabah. The value of murabaha financing in 2014 was $61.89 \%$ of the total financing, while the value of musharaka, mudharabah and ijarah was 27, 14\%, 5.68\%, and 1.29\% respectively. However, in July 2020, murabaha financing decreased to $55.38 \%$, musharaka increased to $38.15 \%$, and mudaraba was $1.75 \%$ which tended to decrease from the previous years. The development of murabahah, musharakah, and mudharabah financing are shown in Figure 1.

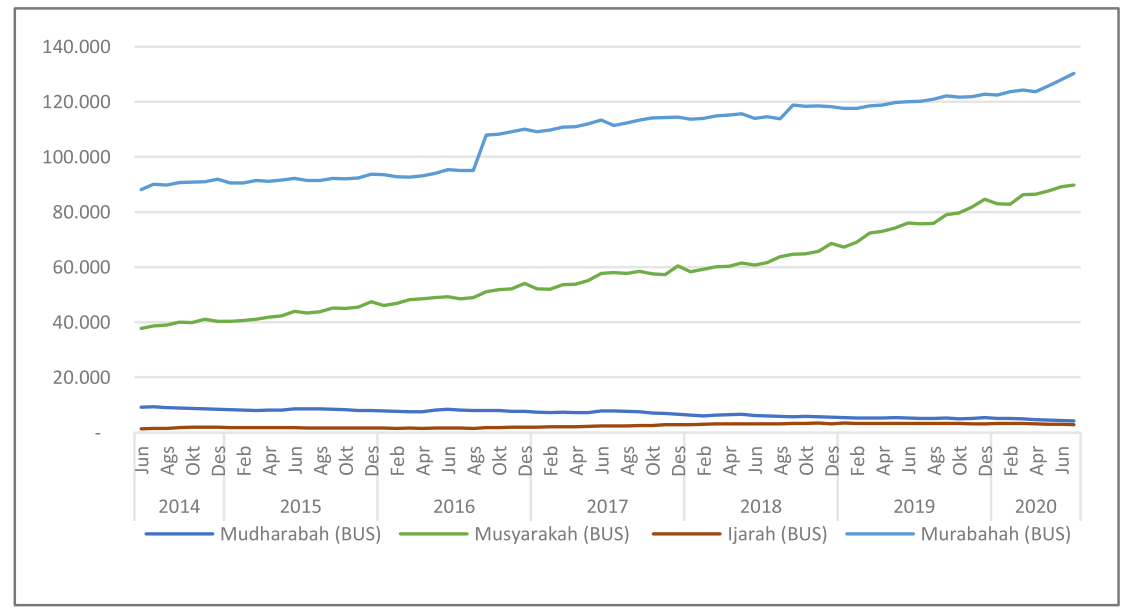

Source: OJK, July 2020

Figure 1. Financing Growth in Islamic Bank (billion) 
Several research found that Islamic bank financing is influenced by bank-specific, macroeconomic variables. Meslier, Risfandy, and Tarazi (2020) and Risfandy, Harahap, Hakim, Sutaryo, Nugroho, and Trinugroho (2020) observed that total assets (SIZE) affect financing. Meanwhile, Lin and Yang, (2016), Meslier et al., (2020), and Risfandy et al., (2020) stated that financing is influenced by profitability (ROA). Other research showed that certain variables such as efficiency (EFF) (Al-Gasaymeh, 2016; Mokhtar, Abdullah, \& Alhabshi, 2008) and financing risk (NPF) (Abedifar et al., 2013; Diallo, Fitrijanti \& Tanzil, 2015) affect financing, among others. Other variables may also play a role such as the interest rate variable (INTR) (Seho, Bacha, \& Smolo, 2020) and inflation (Meslier et al., 2020).

According to Dusuki and Abdullah (2007), equity is an ideal financing model in Islamic banks. Equity financing will provide solutions to improve economic justice following maqasid sharia and consists of musharaka and mudhrarabah (Asutay, 2007). Musharaka is a contract between the bank as the owner of the funds and the depositor, where the bank and the partner issue funds for use by the customer and/or a third party who manages the business fund. PLS is based on a profit sharing ratio agreed upon at the time of the contract between the bank, customer, and/or manager(Ariffin et al., 2015). Meanwhile, mudharabah is a contract between the bank and the customer, in which the bank as the owner of the funds, finances the customer to run a business.

Murabaha is a debt financing, where the bank owns the funds and the customer is the user(Obaidullah, 2008). Customers apply for mudharabah financing to purchase consumptive goods such as motorbikes, cars, or houses. The bank finds the distributor of the goods needed through the customer and then pays by cash. Afterwards, the distributor sends the goods to the customer. The customer then pays to the bank in installments (Wulandari, Putri, Kassim, \& Sulung, 2016). Murabaha financing obtains a larger portion than others due to the risk of asymmetric information(Aggarwal \& Yousef, 2000; Chong \& Liu, 2009; Hamza \& Saadaoui, 2013). Meanwhile, ijarah is a lease contract between the bank as the owner of the goods, and the customer (Fianto, Gan, Hu, \& Roudaki, 2018). In its development, banks do not only provide goods as objects for rent but also in form of services to customers, such as education fees and travel expenses.

Bank size becomes the basis for directors to allocate funds to sources of productive income (Cihak \& Hesse, 2010). Bank assets are not solely used for distribution in form of financing but also through derivatives, acceptance receivables, equity participation, administrative account transactions, and other fund providers. This situation makes the use of assets not only used to be allocated for financing but also distributed to several sources of 
income (Sudarsono \& Saputri, 2018). Meslier et al. (2020), stated that asset size does not affect equity financing as banks have more priority in debt financing. This means that bank size affects SP financing more than PLS because debt financing is more promising for definite profits. Banks with a large size tend to channel more financing than small ones (Kashyap \& Stein, 2000). Therefore, it is expected that bank size will have a positive effect on both equity and debt financing.

ROA is the basis for directors to allocate funds in several potential financing. The ROA obtained from one financing will be the basis for the directors to prioritize funds on that financing. In previous research, Risfandy et al. (2020) observed a negative relationship between ROA and equity financing. This occurred because production sharing tends to provide uncertain profits. Meanwhile, Meslier et al. (2020) found no relationship between ROA and revenue sharing in several Islamic countries. This result confirms that Islamic banks tend to prefer financing that has the potential to generate greater profits than selecting to finance potentially uncertain and risky results. Kim and Sohn (2017) stated that higher ROA tends to have a good balance sheet and allows banks to diversify their financing portfolios through the use of riskier financing. Therefore, it is expected that ROA has a positive effect on equity and debt financing.

Efficiency shows the bank's ability to take advantage of the income earned to generate maximum profit (Sudarsono, 2017). Higher efficiency tends to affect bank management to increase financing (Al-Gasaymeh, 2016; Mokhtar et al., 2008; Risfandy et al., 2020). Islamic banks increase efficiency by making maximum use of technology and employees. However, not all banks have sufficient funds to provide modern technology and professional employees (Al-Ajlouni \& Al-Hakim, 2018). Therefore, banks with large assets tend to be more efficient because they have many opportunities to take advantage of production inputs to generate profits (Kassim \& Majid, 2010; Srairi, 2013). Therefore, it can be assumed that efficiency has a positive effect on both equity and debt financing.

Chiang (2019) implied that the risk of financing is a source of uncertainty in the banking system. Abedifar et al. (2013) stated that the risk management of conventional banks is better than Islamic banks, as the financing system is different from conventional banks. Equity financing in Islamic banks has the potential for a higher risk of financing compared to debt financing or credit at conventional banks. The character of equity financing tends to present moral hazards due to the relatively higher level of asymmetric information compared to debt financing (Alsyahrin, Atahau, \& Robiyanto, 2018; Diallo et al., 2015). Furthermore, it is expected that the NPF will negatively affect both equity and debt financing. 
The INTR is expected to have a negative relationship with financing because customers tend to shift financing from the conventional to Islamic banks when interest rates increase. However, Aysan et al. (2018), Chong and Liu, (2009), Ergeç and Arslan (2013) also Kasri and Azzahra, (2020) found that the interest rate does not affect financing. Islamic banks follow the interest rate, therefore, the increase in the interest rate is followed by increasing margins and the average PLS in Islamic banks (Seho et al., 2020). Meanwhile, high inflation causes people's ability to buy goods and services to decrease, and production to decline (Nursyamsiah, 2018). This situation makes companies tend to reduce or cancel financing (Adebola \& Yusoff, 2011). Therefore, it is expected that inflation will have a negative effect on both equity and debt financing.

Research on the effect of the financial performance of Islamic banks in Indonesia on both equity and debt financing has been carried out such as by Meslier et al., (2020) and Risfandy et al., (2020). However, previous research rarely examines the financial performance of Islamic banks on equity and debt financing in the same period. Therefore, this research aims to analyze the difference in the effect of financial performance in Islamic banks on both equity and debt financing in the same period.

\section{METHOD}

This research conducted from June 2014 to July 2020 in 12 Islamic banks in Indonesia. The dependent variable data reports consisting of mudharabah, musharaka, and murabaha financing was obtained from the Financial Services Authority (OJK, 2021). Furthermore, bank-specific dependent variables such as SIZE, ROA, and NPF were derived from the OJK report in July 2020. Macroeconomic variables such as INTR and inflation rate (INFL) were obtained from the Central Bureau of Statistics (BPS, 2021).

The dependent variable uses the formula performed by Meslier et al. (2020). Specifically, this dependent variable was equity financing which consists of the ratio of mudharabah to total financing (MDF), financing to total assets (MDA), musyarakah to total financing (MSF), and musyarakah to total assets (MSA). Debt financing consisted of a ratio between murabaha with total financing (MRF) and mudharabah financing to total assets (MRA). Meanwhile, the independent variables used include SIZE, ROA, efficiency (EFF), NPF, INTR, and INFL.

The independent variable was based on Adebola and Yusoff, (2011), Al-Gasaymeh, (2016), Amelia and Hardini (2017), Cihak and Hesse, (2010), Kim and Sohn (2017), Nursyamsiah, (2018), Sufian and Majid, (2009), and Zulkhibri, (2018). The specific variable of Islamic banks consists of the size of the bank (SIZE), calculated from the natural logarithm of 
$1 \%$ of the total productive assets of Islamic banks. The high size showed that the bank can mobilize external funds to generate profits through financing (Alandejani, Kutan, \& Samargandi, 2017). Meanwhile, ROA is the ratio of return to total assets. It is used to measure the ability of assets to generate profits in a certain period. High ROA shows that banks can optimize financing to generate profits (Meslier et al., 2020).

The efficiency of Islamic banks (EFF) is calculated from the ratio of operational financing to operating income (Efthyvoulou \& Yildirim, 2014). EFF is interpreted as an indicator to determine the extent to which Islamic banks can utilize their income to perform bank operational activities (Sudarsono, 2017). If the EFF value is low, this signifies that the bank does not optimize bank activities. If the EFF is very high, then the bank is not able to manage its revenue financing properly (Meslier et al., 2020). Meanwhile, non-performing financing (NPF) is the ratio between non-performing financing to total financing. The higher the NPF, the lower the chance for Islamic banks to make profits from financing(Diallo et al., 2015).

Due to the INTR being a macroeconomic variable, an increase in interest increases the competitiveness of Islamic bank financing against credit in conventional banks. Meanwhile, the INF or the percentage level of the general price will increase at a certain period (Seho et al., 2020). High inflation will reduce the ability of customers to consume, thereby causing financing to decline(Amelia \& Hardini, 2017; Meslier et al., 2020).

The ARDL estimation method is a dynamic regression model to analyze the effect of Islamic bank financial performance on equity and debt financing. The ARDL regression method begins with testing stationary data to determine whether the data shows an equilibrium or disequilibrium condition. The stationary data was based on the Augmented Dickey-Fuller (ADF) and Philip Perron (PP) statistical values obtained from the $t$ count and the Mackinnon critical value. When the ADF (PP) is greater than the critical Mackinnon value, the data used in the model is stationary. The ARDL model equations for the musharaka, mudharabah, and murabaha financing equations are as follows:

$\Delta$ Financing $_{t}=\alpha_{0}$

$$
\begin{aligned}
& +\sum_{i=1}^{n} \beta_{1 i} \Delta \text { Financing }_{t-1}+\sum_{i=1}^{n} \beta_{2 i} \Delta S I Z E_{t-1}+\sum_{i=1}^{n} \beta_{3 i} \Delta R O A_{t-1} \\
& +\sum_{i=1}^{n} \beta_{4 i} \Delta B O P O_{t-1}+\sum_{i=1}^{n} \beta_{5 i} \Delta N P F_{t-1}+\sum_{i=1}^{n} \beta_{6 i} \Delta I N T R_{t-1} \\
& +\sum_{i=1}^{n} \beta_{7 i} \Delta I N F L_{t-1}+\delta_{1} \text { Financing }_{t-1}+\delta_{2} \text { SIZE }_{t-1}+\delta_{3} \text { ROA }_{t-1}+\delta_{4} \text { BOPO }_{t-1} \\
& +\delta_{5} N P F_{t-1}+\delta_{6} I_{N T R_{t-1}}+\delta_{7} I N F_{t-1}+e_{t}
\end{aligned}
$$


$\Delta$ is the first different operator, $\alpha_{0}$ is the drift component, $\beta_{j i}$ and $\delta_{j}$ are the approximate coefficients, while $e_{t}$ is the white noise residue. The coefficients of the first to seven estimates with the sum sign $\left(\beta_{1 i}-\beta_{7 i}\right)$ and $\left(\delta_{1}-\delta_{7}\right)$ are related to the short and long-run relationships.

The Bound testing approach(Pesaran et al., 2001) was applied to test the existence of a long-term relationship or cointegration test between financing, ZScore, SIZE, ROA, NPF, INTR, and INFL. The bound test procedure is based on the F test and hypothesizes that there is no cointegration between the variables tested. The alternative hypothesis states that there is cointegration between variables. The critical $F$ value of the cointegration test is based on the critical value developed by (Pesaran et al., 2001). Furthermore, the ARDL version of the error correction modal (ECM) is modeled as follows:

$$
\begin{aligned}
\Delta \text { Financing }_{t} & =\gamma_{0} \\
& +\sum_{i=1}^{n} \theta_{1 i} \Delta \text { Financing }_{t-1}+\sum_{i=1}^{n} \theta_{2 i} \Delta S I Z E_{t-1}+\sum_{i=1}^{n} \theta_{3 i} \Delta R O A_{t-1} \\
& +\sum_{i=1}^{n} \theta_{4 i} \Delta B O P O_{t-1}+\sum_{i=1}^{n} \theta_{5 i} \Delta N P F_{t-1}+\sum_{i=1}^{n} \theta_{6 i} \Delta I N T R_{t-1} \\
& +\sum_{i=1}^{n} \theta_{7 i} \Delta I N F L_{t-1}+\delta E C T_{t}
\end{aligned}
$$

\section{RESULT AND DISCUSSION}

Table 1 describes the statistical descriptions of the variables from June 2017 to July 2020. The average murabaha financing to average assets (MRA) was 42,331 and higher than the average value of the other dependent variables; MDF, MSF, MRF, MDA, and MSA. The standard deviation of the MRA had a value of $3.926 \%$. This value indicates that the MRA is relatively more volatile than the other dependent variables. Meanwhile, the average ROA variable had a value below the provisions of the Indonesian bank, namely $1.5 \%$. The standard deviation of ROA was $0.446 \%$ which indicates that the fluctuation of ROAdata is quite low. On the other hand, the standard deviation of EFF is $4.581 \%$, which means that the value of EFF is relatively volatile compared to other independent variables. The average NPF value was 4,518, and this value is included in the healthy criteria according to Bank Indonesia regulations. Furthermore, the average INFL is 3.994 lower than the average INTR, although the fluctuation of inflation is relatively higher than the INTR. 
Table 1. Statistical Description

\begin{tabular}{cccccc}
\hline Variable & Obs & Mean & Std. Dev. & Min & Max \\
\hline MDF & 74 & 3.981 & 1.342 & 1.745 & 6.373 \\
\hline MSF & 74 & 31.695 & 3.294 & 24.679 & 38.204 \\
\hline MRF & 74 & 59.550 & 2.473 & 54.263 & 62.628 \\
\hline MDA & 74 & 2.876 & 1.113 & 1.172 & 4.908 \\
\hline MSA & 74 & 22.386 & 1.531 & 20.160 & 26.151 \\
\hline MRA & 74 & 42.331 & 3.926 & 35.360 & 49.330 \\
\hline SIZE & 74 & 12.444 & 0.206 & 12.138 & 12.766 \\
\hline ROA & 74 & 1.013 & 0.446 & 0.160 & 1.880 \\
\hline EFF & 74 & 91.945 & 4.581 & 82.780 & 99.040 \\
\hline NPF & 74 & 4.518 & 0.828 & 3.230 & 6.170 \\
\hline INTR & 74 & 5.747 & 1.241 & 4.000 & 7.750 \\
\hline INFL & 74 & 3.994 & 1.493 & 1.540 & 8.360 \\
\hline
\end{tabular}

The results of the stationarity test using the ADF and PP methods are shown in Table 2. The results showed that the variables MDF, MSF, MRF, MDA, MSA, MRA, SIZE, ROA, EFF, NPF, INTR are not stationary at level 1 (0). Furthermore, the results of the following ADF and PP showed that all variables are stationary at the first difference I (1). These results indicate that the right model to estimate is the ARDL model, as the level of integration of each variable is different.

Table 2. Root Test Unit: ADF and PP

\begin{tabular}{ccccc}
\hline \multirow{2}{*}{ Variables } & \multicolumn{2}{c}{ Augmented Dickey-Fuller test } & \multicolumn{2}{c}{ Philip-Perron test } \\
\cline { 2 - 5 } & Level & First Different & Level & First Different \\
\hline MDF & -0.683 & $-8.413^{* * *}$ & -0.678 & $-8.412^{* * *}$ \\
\hline MSF & -0.330 & $-11.487^{* * *}$ & 0.021 & $-11.934^{* * *}$ \\
\hline MRF & -1.463 & $-13.377^{* * *}$ & -0.903 & $-14.328^{* * *}$ \\
\hline MDA & -1.035 & $-6.442^{* * *}$ & -1.012 & $-6.411^{* * *}$ \\
\hline MSA & -1.669 & $-10.403^{* * *}$ & -1.384 & $-10.675^{* * *}$ \\
\hline MRA & -1.064 & $-8.522^{* * *}$ & -1.077 & $-8.522^{* * *}$ \\
\hline SIZE & -0.179 & $-8.336^{* * *}$ & -0.188 & $-8.337^{* * *}$ \\
\hline ROA & -1.714 & $-10.663^{* * *}$ & -1.574 & $-10.662^{* * *}$ \\
\hline EFF & -0.904 & $-9.083^{* * *}$ & -0.857 & $-9.087^{* * *}$ \\
\hline NPF & -1.329 & $-10.865^{* * *}$ & -1.070 & $-11.151^{* * *}$ \\
\hline INTR & -0.73 & $-5.93^{* * *}$ & -0.993 & $-6.053^{* * *}$ \\
\hline INFL & -1.784 & $-7.557^{* * *}$ & -1.929 & $-7.585^{* * *}$ \\
\hline
\end{tabular}

Noted: ${ }^{*} p<0.05,{ }^{* *} p<0.01,{ }^{* * *} p<0.001$

Selection of the best ARDL model with the optimal lag combination in Islamic banks was carried out based on Akaike Info Criterion (AIC). Based on AIC selection, the best ARDL model for this research was ARDL $(1,0,0,0,0,0,0)$ for MDF, $(2,0,0,0,0,0,0)$ for MDS, $(3,0,0,0,0,0,0)$ for MSF, $(3,2,0,0,0,0,0)$ for MSA, $(2,0,0,0,0,4,1)$ for the MRF, $(1,1,0,0,0,0,0)$ 
for the MRA. The R-Squared Adjusted value of the four models in Islamic Commercial Bank (BUS) and Islamic Business Unit (UUS) showed that most of the variations in the financing variables can be explained by each of the selected independent variables of the ARDL model.

From the results of ARDL data processing in Table 3, the SIZE had a negative effect on the MDF, MDA, MSF, MSA, MRF, and MRA models at the 5\% and $1 \%$ classification levels. Meanwhile, ROA had a negative effect on MDA at the $1 \%$ level of certification. NPF had a negative effect on MDF, MSA, and MRA. The INT also had a negative effect on the MDA, MSF, and MRA, while the INFL has a negative effect on the MRF. Meanwhile, SIZE has an effect on both equity and debt financing.

Table 3. ARDL Estimation Result

\begin{tabular}{|c|c|c|c|c|c|c|c|c|c|c|c|c|}
\hline & \multicolumn{2}{|c|}{ MDF_ICB } & \multicolumn{2}{|c|}{ MDA_ICB } & \multicolumn{2}{|c|}{ MSF_ICB } & \multicolumn{2}{|c|}{ MSA_ICB } & \multicolumn{2}{|c|}{ MRF_ICB } & \multicolumn{2}{|c|}{ MRA_ICB } \\
\hline & Coef. & t-Stat & Coef. & $\mathrm{t}$-Stat & Coef. & $\mathrm{t}$-Stat & Coef. & t-Stat & Coef. & t-Stat & Coef. & t-Stat \\
\hline L.MDF & $0.718^{* * *}$ & 7.79 & & & & & & & & & & \\
\hline L.MDS & & & $0.815^{* * *}$ & 7.84 & & & & & & & & \\
\hline L2.MDS & & & $-0.247^{* *}$ & -2.75 & & & & & & & & \\
\hline L.MSF & & & & & $0.474^{* * *}$ & 4.76 & & & & & & \\
\hline L2.MSF & & & & & 0.132 & 1.22 & & & & & & \\
\hline L3.MSF & & & & & $0.262^{*}$ & 2.51 & & & & & & \\
\hline L.MRA & & & & & & & $0.644^{* * *}$ & 5.28 & & & & \\
\hline L2.MRA & & & & & & & 0.110 & 0.82 & & & & \\
\hline L3.MRA & & & & & & & $0.219^{* *}$ & 3.32 & & & & \\
\hline L.SIZE & & & & & & & $20.10^{* *}$ & 2.91 & & & $21.98^{* *}$ & 3.34 \\
\hline L2.SIZE & & & & & & & $11.06^{*}$ & 2.25 & & & & \\
\hline L.MRF & & & & & & & & & $0.256^{* * *}$ & 4.04 & & \\
\hline L2.MRF & & & & & & & & & $0.233^{* *}$ & 3.39 & & \\
\hline L.INTR & & & & & & & & & 0.680 & 1.45 & & \\
\hline L2.INTR & & & & & & & & & 0.307 & 0.68 & & \\
\hline L3.INTR & & & & & & & & & -0.405 & -0.89 & & \\
\hline L4.INTR & & & & & & & & & $-0.852^{*}$ & -2.55 & & \\
\hline L.INFL & & & & & & & & & $-0.345^{* *}$ & -2.88 & & \\
\hline SIZE & $-1.510^{*}$ & -2.45 & $-2.711^{* * *}$ & -6.87 & 0.668 & 0.57 & $-32.51^{* * *}$ & -9.00 & $-4.265^{* *}$ & -2.93 & $-36.75^{* * *}$ & -6.65 \\
\hline ROA & 0.0824 & 0.49 & $-0.373^{* * *}$ & -3.47 & -1.332 & -1.98 & -0.363 & -0.48 & 1.778 & 1.92 & -0.773 & -0.65 \\
\hline EFF & -0.00620 & -0.28 & $-0.0572^{* * *}$ & -4.05 & -0.184 & -1.98 & -0.0123 & -0.12 & $0.307^{*}$ & 2.46 & -0.0112 & -0.07 \\
\hline NPF & $0.120^{*}$ & 2.64 & 0.0143 & 0.51 & -0.103 & -0.65 & $-0.480^{* * *}$ & -3.47 & 0.213 & 1.20 & $-1.398^{* * *}$ & -4.81 \\
\hline INTR & -0.00247 & -0.10 & $-0.0360^{*}$ & -2.38 & $0.246^{* *}$ & 2.95 & -0.00537 & -0.08 & -0.167 & -0.58 & $-0.707^{* * *}$ & -4.43 \\
\hline INFL & 0.0298 & 1.55 & 0.0215 & 1.83 & -0.0790 & -1.05 & -0.0749 & -1.30 & $0.265^{*}$ & 2.34 & -0.00537 & -0.05 \\
\hline cons & $19.71^{*}$ & 2.21 & $40.65^{* * *}$ & 7.22 & 13.84 & 0.63 & 21.94 & 0.83 & $55.50^{*}$ & 2.17 & $214.7^{* * *}$ & 5.15 \\
\hline $\bar{N}$ & 70 & & 70 & & 70 & & 70 & & 70 & & 70 & \\
\hline
\end{tabular}

Noted: ${ }^{*} p<0.05,{ }^{* *} p<0.01,{ }^{* * *} p<0.001$

The subsequent evaluation was the cointegration test using the Bound testing approach. Table 4 presents the results where the calculated $\mathrm{F}$ value and the right side represent the critical $F$ value at various levels of classification based on the $F$ distribution developed by Pesaran et al. (2001). The critical value consists of the upper limit I (1) and the lower limit I (0). In the MDF and MDA models, the calculated F values were 2,324 and 2,618. The F value calculated above was from I (1) at 10\% certification, therefore, there was a cointegration between variables. In conclusion, there is a long-term relationship between the MDF and MDA 
variables with the variables SIZE, ROA EFF, NPF, INTR, and INFL. Meanwhile, in the MSF, MRF, MSA, and MRA models, the calculated F value was greater than I (1) at $1 \%$ specification, therefore all models have a long-term relationship.

Table 4. Bound Test Result

\begin{tabular}{lrrrrrrr}
\hline \multirow{2}{*}{ Model } & \multirow{2}{*}{ F-test } & \multicolumn{2}{c}{$10 \%$} & \multicolumn{2}{c}{$5 \%$} & \multicolumn{2}{c}{$1 \%$} \\
\cline { 3 - 8 } & & $\mathrm{I}(0)$ & $\mathrm{I}(1)$ & $\mathrm{I}(0)$ & $\mathrm{I}(1)$ & $\mathrm{I}(0)$ & $\mathrm{I}(1)$ \\
\hline MDF & 2.324 & 2.254 & 3.422 & 2.648 & 3.923 & 3.537 & 5.035 \\
\hline MSF & 9.217 & 2.234 & 3.434 & 2.627 & 3.943 & 3.516 & 5.075 \\
\hline MRF & 4.090 & 2.254 & 3.422 & 2.648 & 3.923 & 3.537 & 5.035 \\
\hline MDA & 2.618 & 2.247 & 3.426 & 2.641 & 3.93 & 3.53 & 5.048 \\
\hline MSA & 12.758 & 2.26 & 3.447 & 2.66 & 3.963 & 3.571 & 5.116 \\
\hline MRA & 5.897 & 2.26 & 3.447 & 2.66 & 3.963 & 3.571 & 5.116 \\
\hline
\end{tabular}

Table 5 presents the short-term estimation results with ECM ARDL. The first step was to test the validity of the ECM ARDL model by evaluating the significance of ADJ. The ADJ must be negative and statistically significant as the error-correcting variable. The results of data processing showed that SIZE had a negative effect on MSA and MRA at 5\% certification. Meanwhile, INTR at lag 1 to lag 3 had a positive effect on MR.

Table 5. Short-Term and Long-Term Estimation Result

\begin{tabular}{|c|c|c|c|c|c|c|c|c|c|c|c|c|}
\hline & \multicolumn{2}{|c|}{ MDF } & \multicolumn{2}{|c|}{ MDA } & \multicolumn{2}{|c|}{ MSF } & \multicolumn{2}{|c|}{ MSA } & \multicolumn{2}{|c|}{ MRF } & \multicolumn{2}{|c|}{ MRA } \\
\hline & \multicolumn{2}{|c|}{ (1) } & \multicolumn{2}{|c|}{ (2) } & \multicolumn{2}{|c|}{ (3) } & \multicolumn{2}{|c|}{ (4) } & \multicolumn{2}{|c|}{ (5) } & \multicolumn{2}{|c|}{ (6) } \\
\hline & Coef. & t-Stat & Coef. & t-Stat & Coef. & t-Stat & Coef. & t-Stat & Coef. & t-Stat & Coef. & t-Stat \\
\hline ADJ & $-0.282^{* *}$ & -3.07 & $-0.433^{* * *}$ & -6.47 & $-0.131^{* *}$ & -2.72 & -0.0266 & -0.52 & $-0.510^{* * *}$ & -7.32 & $-0.438^{* * *}$ & -4.61 \\
\hline \multicolumn{13}{|l|}{ Long Run } \\
\hline SIZE & $-5.345^{* * *}$ & -4.68 & $-6.264^{* * *}$ & -12.13 & 5.088 & 0.54 & -50.95 & -0.63 & $-8.354^{* *}$ & -2.92 & $-33.68^{* * *}$ & -6.33 \\
\hline ROA & 0.292 & 0.48 & $-0.863^{* *}$ & -3.01 & $-10.14^{*}$ & -2.13 & -13.65 & -0.51 & $3.483^{*}$ & 2.22 & -1.763 & -0.62 \\
\hline EFF & -0.0220 & -0.28 & $-0.132^{* *}$ & -3.32 & $-1.405^{*}$ & -2.32 & -0.463 & -0.13 & $0.601^{* *}$ & 2.94 & -0.0256 & -0.07 \\
\hline NPF & $0.423^{*}$ & 2.30 & 0.0329 & 0.50 & -0.781 & -0.65 & -18.05 & -0.54 & 0.416 & 1.18 & $-3.189^{* * *}$ & -5.16 \\
\hline INTR & -0.00873 & -0.10 & $-0.0833^{*}$ & -2.42 & 1.877 & 2.00 & -0.202 & -0.08 & $-0.855^{* * *}$ & -4.45 & $-1.613^{* * *}$ & -5.28 \\
\hline INFL & 0.106 & 1.68 & 0.0497 & 1.91 & -0.602 & -1.22 & -2.814 & -0.58 & -0.157 & -0.92 & -0.0123 & -0.05 \\
\hline \multicolumn{13}{|l|}{ Short Run } \\
\hline LD.MDA & & & $0.247^{* *}$ & 2.75 & & & & & & & & \\
\hline LD.MSF & & & & & $-0.395^{* * *}$ & -3.71 & & & & & & \\
\hline L2D.MSF & & & & & $-0.262^{*}$ & -2.51 & & & & & & \\
\hline LD.MSA & & & & & & & $-0.329^{* *}$ & -2.74 & & & & \\
\hline L2D.MSA & & & & & & & $-0.219^{* *}$ & -3.32 & & & & \\
\hline D.SIZE & & & & & & & $-31.16^{* * *}$ & -7.33 & & & $-21.98^{* *}$ & -3.34 \\
\hline LD.SIZE & & & & & & & $-11.06^{*}$ & -2.25 & & & & \\
\hline LD.MRF & & & & & & & & & $-0.233^{* *}$ & -3.39 & & \\
\hline D.INTR & & & & & & & & & 0.269 & 0.90 & & \\
\hline LD.INTR & & & & & & & & & $0.949^{* *}$ & 3.05 & & \\
\hline L2D.INTR & & & & & & & & & $1.257^{* * *}$ & 4.02 & & \\
\hline L3D.INTR & & & & & & & & & $0.852^{*}$ & 2.55 & & \\
\hline $\begin{array}{l}\text { D.INF } \\
\end{array}$ & & & & & & & & & $0.345^{* *}$ & 2.88 & & \\
\hline cons & $19.71^{*}$ & 2.21 & $40.65^{* * *}$ & 7.22 & 13.84 & 0.63 & 21.94 & 0.83 & $55.50^{*}$ & 2.17 & $214.7^{* * *}$ & 5.15 \\
\hline N & 70 & & 70 & & 70 & & 70 & & 70 & & 70 & \\
\hline
\end{tabular}

Noted: ${ }^{*} p<0.05,{ }^{* *} p<0.01,{ }^{* * *} p<0.001$ 
In the long term, it was observed that SIZE had a negative effect on MDF, MDA, MRF, and MRA at a $1 \%$ classification level. ROA and EFF have a negative effect on MDA, MSF, and MRF. NPF has a positive effect on MDF but a negative effect on MRA. Meanwhile, INTR shows a negative relationship with MDA, MRF, and MRA, while INFL has no effect on all models.

SIZE shows a negative relationship with MDF, MDA, and MSA. The relationship is estimated because it has a standard deviation of 0.206 , which means that it does not relatively fluctuate or tends to increase constantly in the research period. However, the percentage growth of MDF and MDA tended to decrease. MSF and MSA increased relatively, while MRF and MRA tended to increase during the research period. The absence of SIZE influence on musharaka financing (MSF) was similar to the result by Meslier et al., (2020). In general, this result is at variance with Kashyap and Stein, (2000) which stated that a small SIZE tends to reduce financing.

Long-term ROA has a negative effect on MDS and MSF, but has a positive effect on MRF. Islamic banks pay more attention to ROA as a reference for increasing murabaha financing. Increasing ROA indicates an increase in the percentage of murabaha financing, as well as a decrease in both mudharabah and musharaka financing. Therefore, Islamic banks tend to be more conservative in channeling financing. On the other hand, the non-impact of ROA on MDF is in line with Meslier et al., (2020) which observed that ROA is not the main factor for Islamic bank management in determining the portion of the financing. This result is also different from Kim and Sohn, (2017) which stated that higher ROA will make Islamic banks more likely to diversify in riskier financing.

The level of efficiency calculated from the ratio of operational costs to income (EFF) has no effect on MDF, MSA, and MRA, but has a negative effect on MDA, MSF, and MRF. Efficiency can be characterized by the bank's ability to utilize technology more efficiently through the use of more specialized staff(Al-Ajlouni \& Al-Hakim, 2018). Bank size is one of the factors that affect the level of efficiency (Kassim \& Majid, 2010). The negative relationship between efficiency and PLS, and buying and selling can be interpreted that those Islamic banks have been able to optimize the resources they have to generate maximum profits. This is marked by the increasing use of electronic transaction (e-banking) services, phone and internet banking, as well as using various types of credit cards, point of sales, electronic fund transfers, and clearing automation in Islamic banks. In addition, customers have relatively easy access, such as opening accounts, applying for loans online, no longer need to visit outlets or branch offices. 
NPF is positively related to MDF and negatively related to MRA. The positive influence between NPF and MDF is in accordance with Alsyahrin et al., (2018). On the other hand, the negative effect of NPF on MRA is in accordance with Diallo et al., (2015) where the high financing value has the potential to increase the risk of financing. In the PLS system for mudharabah and musharaka financing, the bank earns an uncertain profit. If the customer generates high profits, the PLS obtained by the bank is also high. Although mudharabah financing always produces low profits, Islamic banks cannot remove this financing because Islamic banks are identical to PLS. Islamic banks tend to give a low portion of PLS financing to avoid the risks. The average portion of murabaha financing is $39.87 \%$ of the total, and this value is greater than the portion of mudharabah financing $(9.68 \%)$ during the research period. This necessitates a concern of NPF level in Islamic bank management while channeling murabaha financing.

The regression results showed that the INTR has a negative effect on MDF and MDA. This is in line with Seho et al., (2020) which observed a negative relationship between INTR and murabaha financing. However, these results are different from several research by Chong and Liu (2009), Cihak and Hesse (2010), Ergeç and Arslan, (2013) and Kasri and Azzahra, (2020) which observed that INTR does not have an effect on murabaha financing. The nonimpact of INTR is due to the tendency for murabaha financing to be similar to the credit system in conventional banks.

The inflation variable does not influence mudharabah financing. This is in line with the results of Amelia and Hardini, (2017) and Seho et al., (2020) which found that the INFL does not influence Islamic bank financing. However, it is different from Kassim and Majid (2010) and Nursyamsiah, (2018) which observed a negative relationship between inflation and financing. The increase in inflation is an indication of decreasing public purchasing power, which will reduce the level of company production. This situation will cause the company's demand for bank financing to decline.

\section{CONCLUSION}

Financial performance has more influence on debt than equity financing. This shows that a bank management pays more attention to their financial performance before carrying out debt financing. The nature of debt financing, which is based on certainty in determining the financing margin, enables the bank management to minimize bank uncertainty in the future. Meanwhile, the financial performance of Islamic banks does not have much effect on bank management to channel financing in form of equity, because banks try to minimize losses 
obtained from income from products that use PLS contracts. Islamic banks are expected to prioritize equity financing as this is more accommodating to the customers' problems. Customers do not always earn income in their business, and the profits obtained are not always the same in each period. Therefore, bank management needs to increase equity by increasing financing control over customers. Financing control can be performed by formulating an appropriate credit scoring model, creating a model of assistance to customers, and developing a financing execution model according to the customer.

\section{BIBLIOGRAPHY}

Abedifar, P., Molyneux, P., \& Tarazi, A. (2013). Risk in Islamic Banking. Review of Finance, 17(6), 2035-2096. https://doi.org/10.1093/rof/rfs041.

Adebola, S. S., Yusoff, W. S. W., \& Dahalan, J. (2011). The Impact of Macroeconomic Variables on Islamic Banks Financing in Malaysia. Research Journal of Finance and Accounting, 2(4), 22-33. Retrieved from https://iiste.org/Journals/index.php/RJFA/ article/view/550.

Aggarwal, R. K., \& Yousef, T. (2000). Islamic Banks and Investment Financing. Journal of Money, Credit and Banking, 32(1), 93-120. https://doi.org/10.2307/2601094.

Al-Ajlouni, A., \& Al-Hakim, D. M. S. (2018). Financial Technology in Banking Industry: Challenges and Opportunities. SSRN Electronic Journal. https://doi.org/10.2139/ ssrn.3340363.

Alam, N., \& Parinduri, R. A. (2017). Do Islamic Banks Shift from Mark-Up to Equity Financing When Their Contracting Environments are Improved? Applied Economics Letters, 24(8), 545-548. https://doi.org/10.1080/13504851.2016.1210759.

Alandejani, M., Kutan, A. M., \& Samargandi, N. (2017). Do Islamic Banks Fail More than Conventional Banks? Journal of International Financial Markets, Institutions and Money, 50, 135-155.https://doi.org/10.1016/j.intfin.2017.05.007.

Al-Gasaymeh, A. (2016). Bank Efficiency Determinant: Evidence from the Gulf Cooperation Council Countries. Research in International Business and Finance, 38, 214-223. https://doi.org/10.1016/j.ribaf.2016.04.018.

Alsyahrin, D. P., Atahau, A. D. R., \& Robiyanto, R. (2018). The Effect of Liquidity Risk, Financing Risk, and Operational Risk toward Indonesian Sharia Bank's Financing with Bank Size as a Moderating Variable. Journal of Economics, Business \& Accountancy Ventura, 21(2). 241-249. https://doi.org/10.14414/jebav.v21i2.1181. 
Amelia, E., \& Hardini, E. F. (2017). Determinant of Mudharabah Financing: A Study at Indonesian Islamic Rural Banking. Etikonomi, 16(1), 43-52. https://doi.org/10.15408 /etk.v16i1.4638.

Ariffin, N. M., Kassim, S. H., \& Razak, D. A. (2015). Exploring Application of Equity-Based Financing through Mushārakah Mutanāqișah in Islamic Banks in Malaysia: Perspective from the Industry Players, International Journal of Economics, Management and Accounting, 2, 241-261. Retrieved from https://journals.iium.edu. my/enmjournal/index.php/enmj/article/view/338.

Asutay, M. (2007). Conceptualisation of the Second Best Solution in Overcoming the Social Failure of Islamic Banking and Finance: Examining the Overpowering of Homoislamicus by Homoeconomicus. IIUMJournal of Economics and Management, 15(2), 167-195. Retrieved from https://journals.iium.edu.my/enmjournal/index.php/ enmj/article/view/134.

Aysan, A. F., Disli, M., \& Ozturk, H. (2018). Bank Lending Channel in A Dual Banking System: Why Are Islamic Banks So Responsive? The World Economy, 41(3), 674-698.https://doi.org/10.1111/twec.12507.

Chiang, T. C. (2019). Financial Risk, Uncertainty and Expected Returns: Evidence from Chinese Equity Markets. China Finance Review International, 9(4), 425-454. https://doi.org/10.1108/CFRI-09-2018-0129.

Chong, B. S., \& Liu, M.-H. (2009). Islamic Banking: Interest-Free or Interest-Based? PacificBasin Finance Journal, 17(1), 125-144.https://doi.org/10.1016/j.pacfin.2007.12.003.

Čihák, M., \& Hesse, H. (2010). Islamic Banks and Financial Stability: An Empirical Analysis. Journal of Financial Services Research, 38(2-3), 95-113. https://doi.org/10.1007 /s10693-010-0089-0.

Diallo, O., Fitrijanti, T., \& Tanzil, N. D. (2015). Analysis of the Influence of Liquidity, Credit and Operational Risk in Indonesian Islamic Bank's Financing for the Period 20072013. Gadjah Mada International Journal of Business, 17 (3), 279-294. https://doi.org/10.22146/gamaijb.8402.

Dusuki, A. W., \& Abdullah, N. I. (2007). Why Do Malaysian Customers Patronise Islamic Banks? International Journal of Bank Marketing, 25(3), 142-160. https://doi.org/10.1108/02652320710739850.

Efthyvoulou, G., \& Yildirim, C. (2014). Market Power in CEE Banking Sectors and the Impact of the Global Financial Crisis. Journal of Banking \& Finance, 40, 11-27. https://doi.org/10.1016/j.jbankfin.2013.11.010. 
Ergeç, E. H., \& Arslan, B. G. (2013). Impact of Interest Rates on Islamic and Conventional Banks: The Case of Turkey. Applied Economics, 45(17), 2381-2388. https://doi.org/10.1080/00036846.2012.665598.

Fianto, B. A., Gan, C., Hu, B., \& Roudaki, J. (2018). Equity Financing and Debt-Based Financing: Evidence from Islamic Microfinance Institutions in Indonesia. PacificBasin Finance Journal, 52, 163-172.https://doi.org/10.1016/j.pacfin.2017.09.010.

Hamza, H., \& Saadaoui, Z. (2013). Investment Deposits, Risk Taking and Capital Decisions in Islamic Banks. Studies in Economics and Finance, 30(3), 244-265. https://doi.org/10.1108/SEF-Feb-2012-0016.

Kashyap, A. K., \& Stein, J. C. (2000). What Do a Million Observations on Banks Say about the Transmission of Monetary Policy? American Economic Review, 90(3), 407-428. https://doi.org/10.1257/aer.90.3.407.

Kasri, R. A., \& Azzahra, C. (2020). Do Islamic Banks More Stable than Conventional Banks? Evidence from Indonesia. Jurnal Ekonomi \& Keuangan Islam, 6(2), 149-164. https://doi.org/10.20885/jeki.vol6.iss2.art6.

Kassim, S. H., \& Majid, M. S. A (2010). Impact of Financial Shocks on Islamic Banks: Malaysian Evidence During 1997 and 2007 Financial Crises. International Journal of Islamic and Middle Eastern Finance and Management, 3(4), 291-305. https://doi.org/10.1108/17538391011093243.

Kim, D., \& Sohn, W. (2017). The Effect of Bank Capital on Lending: Does Liquidity Matter? Journal of Banking \& Finance, 77, 95-107.https://doi.org/10.1016/j.jbankfin.2017. 01.011 .

Lin, C. C., \& Yang, S. L. (2016). Bank Fundamentals, Economic Conditions, and Bank Failures in East Asian Countries. Economic Modelling, 52, 960-966. https://doi.org/10.1016/ j.econmod.2015.10.035.

Meslier, C., Risfandy, T., \& Tarazi, A. (2020). Islamic Banks' Equity Financing, Shariah Supervisory Board, and Banking Environments. Pacific-Basin Finance Journal, 62, 101354. https://doi.org/10.1016/j.pacfin.2020.101354.

Miah, M. D., \& Suzuki, Y. (2020). Murabaha Syndrome of Islamic Banks: A Paradox or Product of the System? Journal of Islamic Accounting and Business Research, 11(7), 1363-1378. https://doi.org/10.1108/JIABR-05-2018-0067.

Mokhtar, H. S. A., Abdullah, N., \& Alhabshi, S. M. (2008). Efficiency and Competition of Islamic Banking in Malaysia. Humanomics, 24(1), 28-48. https://doi.org/10.1108/ 08288660810851450 . 
Nursyamsiah, T. (2018). Macroeconomic Determinants of Islamic Banking Financing. Tazkia Islamic Finance and Business Review, 11(2). https://doi.org/10.30993/tifbr.v11i2.136.

Obaidullah, M. (2008). An introduction to Islamic microfinance. New Delhi: IBF Net Limited.

Pesaran, M. H., Shin, Y., \& Smith, R. J. (2001). Bounds Testing Approaches to the Analysis of Level Relationships. Journal of Applied Econometrics, 16(3), 289-326. https://doi.org/10.1002/jae.616.

Risfandy, T., Harahap, B., Hakim, A. R., Sutaryo, S., Nugroho, L. I., \& Trinugroho, I. (2020). Equity Financing at Islamic Banks: Do Competition and Bank Fundamentals Matter? Emerging Markets Finance and Trade, 56(2), 314-328. https://doi.org/10.1080/ 1540496X.2018.1553160.

Šeho, M., Bacha, O. I., \& Smolo, E. (2020). The Effects of Interest Rate on Islamic Bank Financing Instruments: Cross-Country Evidence from Dual-Banking Systems. Pacific-Basin Finance Journal, 62, 101292. https://doi.org/10.1016/j.pacfin.2020. 101292.

Srairi, S. (2013). Ownership Structure and Risk-Taking Behaviour in Conventional and Islamic Banks: Evidence for MENA Countries. Borsa Istanbul Review, 13(4), 115-127. https://doi.org/10.1016/j.bir.2013.10.010.

Sudarsono, H. (2017). Modelling Respon Rasio Keuangan terhadap Pembiayaan pada Bank Syariah di Indonesia. JESI (Jurnal Ekonomi Syariah Indonesia), 7(1), 1-13. https://doi.org/10.21927/jesi.2017.7(1).1-13.

Sudarsono, H., \& Saputri, M. A. (2018). The Effect of Financial Performance toward PLS Rate on Mudharabah Deposit of Sharia Banking in Indonesia. Muqtasid: Jurnal Ekonomi dan Perbankan Syariah, 9(1), 82-92.https://doi.org/10.18326/muqtasid.v9i1.82-92.

Sufian, F., \& Majid, M. Z. A. (2009). Post-Crisis Productivity Change in Non-Bank Financial Institutions: Efficiency Increase or Technological Progress? Journal of Transnational Management, 14(2), 124-154. https://doi.org/10.1080/15475770903028381.

Wulandari, P., Putri, N. I. S., Kassim, S., \& Sulung, L. A. (2016). Contract Agreement Model for Murabahah Financing in Indonesia Islamic Banking. International Journal of Islamic and Middle Eastern Finance and Management, 9(2), 190-204. https://doi.org/10.1108/IMEFM-01-2015-0001.

Zulkhibri, M. (2018). The Impact of Monetary Policy on Islamic Bank Financing: Bank-Level Evidence from Malaysia. Journal of Economics, Finance and Administrative Science, 23(46), 306-322. https://doi.org/10.1108/JEFAS-01-2018-0011. 